\title{
Molecular pathogenesis in granulosa cell tumor is not only due to somatic FOXL2 mutation
}

\author{
Wen-Chung Wang ${ }^{1}$ and Yen-Chein Lai $^{2 *}$
}

\begin{abstract}
Granulosa cell tumors are rare ovarian malignancies. Their characteristics include unpredictable late recurrent and malignant behavior. Recent molecular studies have characterized the FOXL2 402C > G mutation in adult-type granulosa cell tumor. In this study, we report an 80-year-old woman with a granulosa cell tumor arising from ovary. She presented with a huge pelvic mass with postmenopausal bleeding. No obvious intraperitoneal tumor implants were observed during operation. Final diagnosis was granulosa-theca cell tumor without capsule invasion. No recurrent disease was noted during 3-year post-operation follow-up period. Molecular studies showed a heterozygous FOXL2 402C > G mutation in the tumor by direct gene sequencing. In addition, DNA replication error, on analysis of the lengths of CAG repeats in androgen receptor gene, revealed defective DNA mismatch repair system in the granulosa cell tumor. We propose that the 402C > G mutation in FOXL2 is critical to the development of adult granulosa cell tumor. However, the malignant behavior of this tumor is driven by DNA mismatch repair deficiency. Unequal DNA copy numbers were noted on array comparative genomic hybridization. This implies that there is malignant potential even in the early stage of the granulosa cell tumor. Late malignant recurrence may be a late event of DNA repair function disability, not directly related to pathognomonic FOXL2 mutation.
\end{abstract}

Keywords: Granulosa cell tumor, FOXL2 mutation, Loss of heterozygosity, Array comparative genomic hybridization

\section{Background}

Sex cord-stromal tumors represent approximately $8 \%$ of all ovarian tumors [1]. The incidence is about 0.2 per 100000 women. The most frequently diagnosed tumor type within sex cord-stromal category is the granulosa cell tumor [1]. Granulosa cell tumors may be composed almost exclusively of granulosa cells, but more commonly also contain theca cells, lutein cells, and/or fibroblasts [2]. The granulosa cells in tumor may be arranged in trabecular, insular, grand like, microfollicular, macrofollicular or diffuse cellular patterns [3]. Granulosa cell tumors can be further categorized into two distinct subtypes, juvenile and adult forms [1]. Juvenile granulosa cell tumor is characterized by a modular or diffuse pattern, with follicle-like spaces of variable size and shape and striking cytologic atypia [3]. In some cases, these tumors cannot be distinguished from each other or from other malignant tumors. Recent studies of FOXL2 (forkhead box L2) gene

\footnotetext{
* Correspondence: yenchein@csmu.edu.tw

${ }^{2}$ School of Medical Laboratory and Biotechnology, Chung Shan Medical University, No.110, Sec. 1, Chien Kuo N. Road, Taichung 402, Taiwan Full list of author information is available at the end of the article
}

402C > G $(\mathrm{C} 134 \mathrm{~W})$ mutation may resolve the problems of adult-type granulosa cell tumor diagnosis [4]. Adulttype granulosa cell tumors are much more common and mostly occur in perimenopausal or early postmenopausal females [5].

Granulosa cell tumors are generally considered to have a better prognosis than epithelial ovarian tumors [1]. However, there is high rate of tumor recurrence late in life and approximately $80 \%$ of patients with advanced stage or recurrent tumors succumb to their disease [6]. Granulosa cell tumors with malignant potential comprise 1.0 percent of all ovarian cancers [1]. The characteristics associated with granulosa cell tumors cannot be explained by ploidy or $\mathrm{p} 53$ overexpression $[7,8]$.

\section{Case report}

An 80-year-old woman presented with a clinically detectable pelvic mass. She subsequently underwent laparotomy for total hysterectomy and bilateral salpingooophorectomy. Gross examination demonstrated an ovarian mass with attached fallopian tube, measuring $11.0 \times$ $8.0 \times 7.0 \mathrm{~cm}$, which was brownish in color and elastic. On 


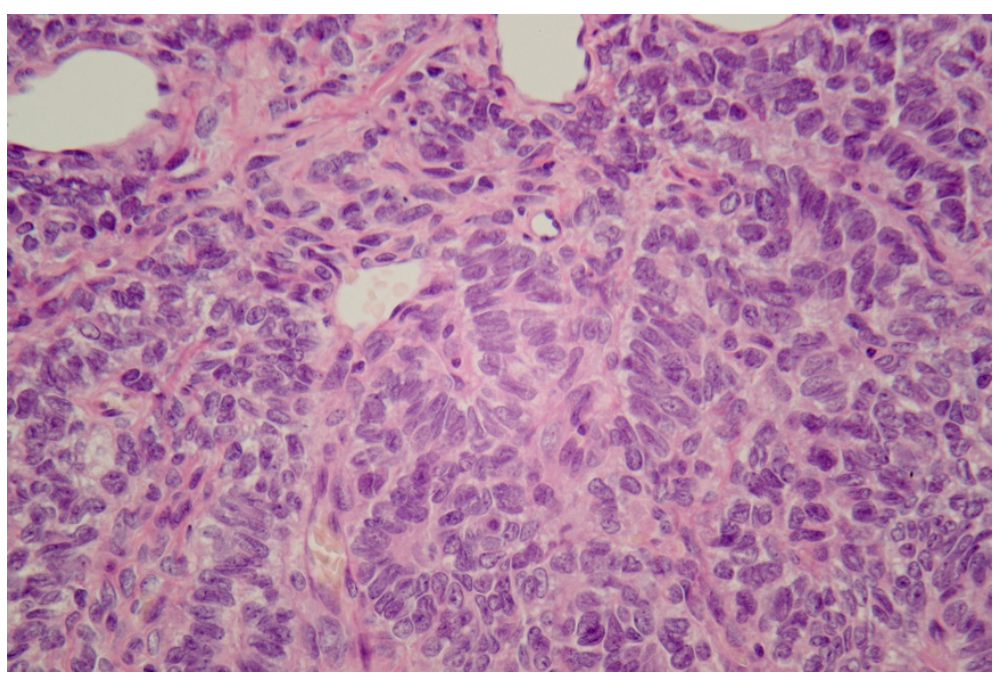

Figure 1 Granulosa cell tumor: Histological cross-section after hematoxylin and eosin staining shows the adult granulosa cell tumor component.

cut, the ovary was yellowish in color and soft. Microscopically, the ovary revealed a granulosa-theca cell tumor characterized by granulosa cells in trabecular or cylindrical pattern and theca cells in spindle pattern (Figure 1). FIGO stage IA was supported by pathological report. Her blood inhibin A and B levels were $47.208 \mathrm{pg} / \mathrm{ml}$ and $92.473 \mathrm{pg} / \mathrm{ml}$, respectively, immediately after operation and $15.533 \mathrm{pg} / \mathrm{ml}$ and $22.331 \mathrm{pg} / \mathrm{ml}$, respectively, one month post-operation. No recurrent disease was noted during 3-year post-operation follow-up period. The Institutional Review Board of Chung Shan Medical University Hospital approved all procedures and informed consent was obtained prior to collecting her genetic material for the study.

We tested for the presence of FOXL2 402C > G mutation using PCR and direct sequencing according to the methods described by Schrader et al [9]. The nucleotide sequence analysis of FOXL2 from the granulosa cell tumor section revealed heterozygous $402 \mathrm{C}>\mathrm{G}$ mutation. In contrast, FOXL2 sequences of genomic DNA isolated from the blood and normal tissue of this patient did not demonstrate this mutation. When compared with DNA from normal cells (Figure 2A), DNA replication error caused by slippage between the replication apparatus and the DNA template was detected in the granulosa cell tumor (Figure 2B), on analysis of the lengths of CAG repeats in androgen receptor gene, using published primers and experimental conditions [10]. In addition, we compared the DNA profiles of normal tissue and tumor tissue using short tandem repeats (STR) analysis according to the methods described by Wang et al [11]. The tumor showed loss of heterozygosity (LOH) for a number of markers (Figure 3 and Table 1). Moreover, based on array comparative genomic hybridization $(\mathrm{CGH})$, pathological
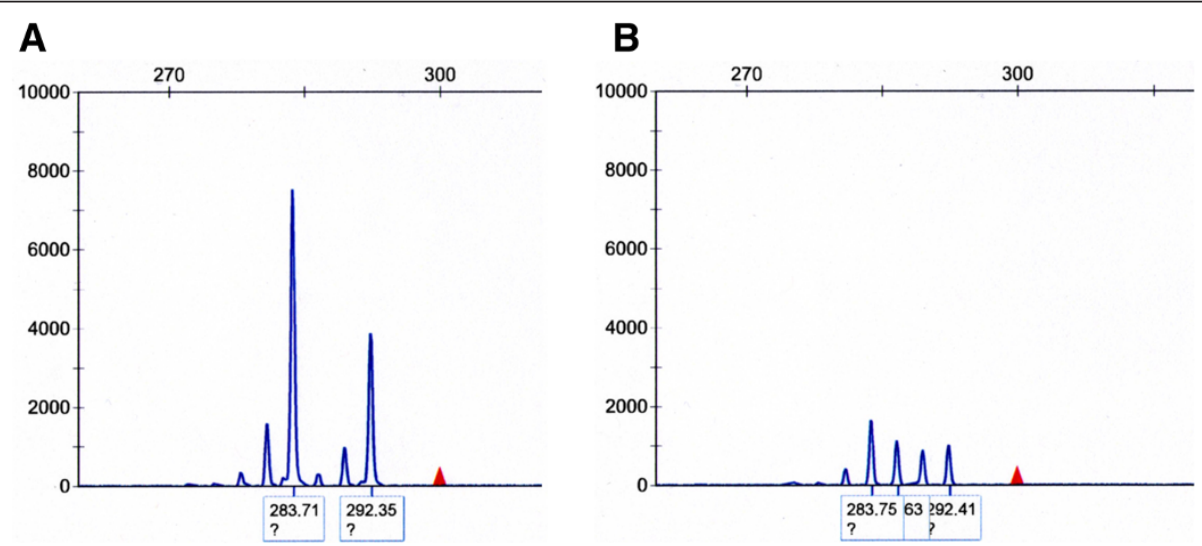

Figure 2 Replication error was detected on analysis of the CAG repeats in androgen receptor gene by capillary gel electrophoresis. DNA from tumor (B) is compared with DNA from normal cells (A) from the same patient. 
genetic imbalances were detected in the tumor on CytoChip Oligo Array (BlueGenome): monosomy 4 and 10; partial monosomy 14 with segmental deletions; and mosaic trisomy $6,11,12,13,15$, and 18 with segmental duplications (Figure 4 and Table 2).

\section{Discussion}

Recent studies have shown that FOXL2 $402 \mathrm{C}>\mathrm{G}$ is a diagnostic characteristic of adult-type granulosa cell tumor [4]. However, little is known about how a granulosa cell tumor undergoes indolent course with late recurrent behavior [12]. We report a case of adult-type granulosa cell tumor with FOXL2 402C > G mutation in an 80-year-old woman, in which one allele was normal and one was mutant. This mutation was not observed in the blood and normal tissue samples of this patient. Histological diagnosis is compatible with adult-type granulosa cell tumor in this case. RNA transcription arrays from granulosa cell tumor cell line have indicated that alteration involves cell death, proliferation and tumorigenesis [13]. However, the mechanism is not clear.

DNA replication error on analysis of the lengths of CAG repeats in androgen receptor gene (Figure 2B) is consistent with a previous study suggesting that a DNA mismatch repair deficiency contributes to the pathogenesis of granulosa cell tumors, and that this deficiency is an early event in their development and/or progression [14]. LOH for a number of markers (Table 1 and Figure 3 ) and pathological genetic imbalances throughout the genome (Table 2 and Figure 4) imply that a defective upstream

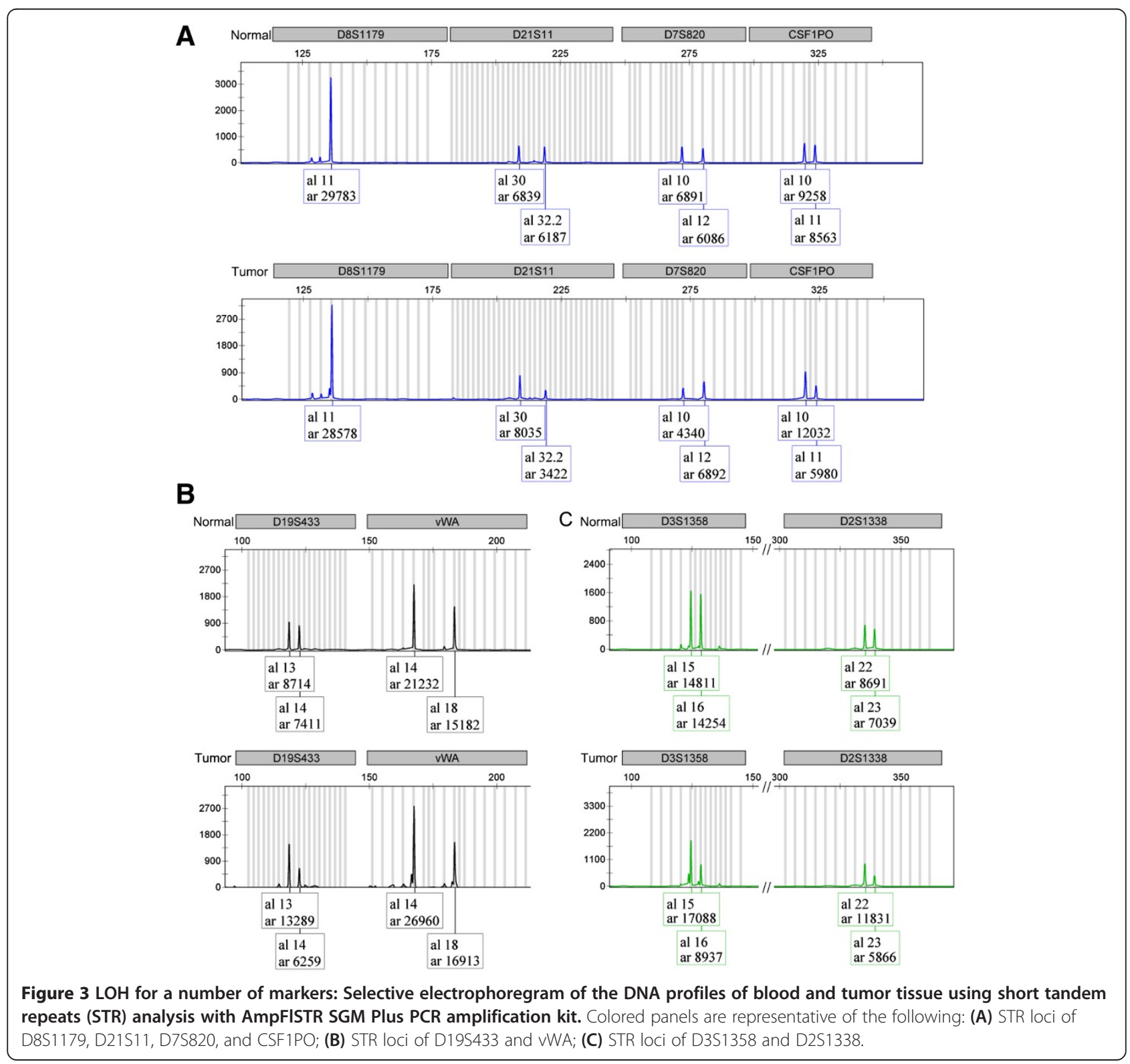


Table 1 Loss of heterozygosity in 15 STR loci of the granulosa cell tumor

\begin{tabular}{llll}
\hline STR Loci & Location & Alleles & $\mathbf{R}^{\mathbf{a}}$ \\
\hline TPOX & $2 \mathrm{p} 23-2 \mathrm{per}$ & 8,8 & $\mathrm{ND}$ \\
D2S1338 & $2 \mathrm{q} 35-37.1$ & 22,23 & $1.63^{\mathrm{b}}$ \\
D3S1358 & $3 \mathrm{p} 21.31$ & 15,16 & $1.84^{\mathrm{b}}$ \\
FGA & $4 q 28$ & 22,23 & 1.01 \\
D5S818 & $5 q 21-31$ & 11,11 & $\mathrm{ND}$ \\
CSF1PO & $5 \mathrm{q} 33.3-34$ & 10,11 & $1.86^{\mathrm{b}}$ \\
D7S820 & $7 q 11.21-22$ & 10,12 & $0.56^{\mathrm{b}}$ \\
D8S1179 & $8 \mathrm{q} 24.1-24.2$ & 11,11 & $\mathrm{ND}$ \\
TH01 & $11 \mathrm{p} 15.5$ & 9,9 & $\mathrm{ND}$ \\
VWA & $12 \mathrm{p} 12-\mathrm{pter}$ & 14,18 & 1.14 \\
D13S317 & $13 q 22-31$ & 10,13 & 0.94 \\
D16S539 & $16 q 24-q$ ter & 9,11 & 1.11 \\
D18S51 & $18 q 21.3$ & 14,18 & 1.06 \\
D19S433 & $19 q 12-13.1$ & 13,14 & $1.81^{\mathrm{b}}$ \\
D21S11 & 21q11.2-q21 & $30,31.2$ & $2.12^{\mathrm{b}}$ \\
\hline
\end{tabular}

${ }^{\mathrm{a}} \mathrm{R}=$ (area T1/area T2)/(area N1/area N2); ${ }^{\mathrm{b} L o s s}$ of heterozygosity (LOH) is positive when $R \geq 1.25$ or $\leq 0.8$ (ie., $20 \%$ change).

regulatory gene is involved in this condition. The $M L H 1$ gene that encodes a component of the mismatch repair system located near the D3S1358 locus showed LOH (Table 1). This implies that the upstream regulatory mechanisms leading to increased DNA replication errors, LOH, and genetic imbalances are associated with $\operatorname{defect}(\mathrm{s})$ in global gene regulation.

Our assumption is that a genetic alteration in mismatch repair system occurs before FOXL2 402C > G mutation. After this mutation is initiated, granulosa cell tumor develops in early tumorigenesis. The genomic imbalances on array $\mathrm{CGH}$ in this study were inconsistent with the results
Table 2 The deleted or duplicated clones and their physical location in the granulosa cell tumor

\begin{tabular}{|c|c|c|c|}
\hline & ISCN nomenclature & Type & Size (bp) \\
\hline 1 & arr $4 p 16.3 q 35.2(37,152-190,896,645) \times 1$ & LOSS & $190,859,493$ \\
\hline 2 & arr $6 \mathrm{p} 25.3 \mathrm{q} 27(163,113-170,921,060) \times 2 \sim 3$ & GAIN & $170,757,947$ \\
\hline 3 & arr 10p15.3q26.3(136,391-135,434,149)×1 & LOSS & $135,297,758$ \\
\hline 4 & arr $11 p 15.5 q 25(196,990-134,868,378) \times 2 \sim 3$ & GAIN & $134,671,388$ \\
\hline 5 & arr 12p13.33q24.33(230,451-133,773,499)×2 3 & GAIN & $133,543,048$ \\
\hline 6 & arr $13 q 12.11 q 34(20,407,324-115,092,619) \times 2 \sim 3$ & GAIN & $94,685,295$ \\
\hline 7 & arr $14 q 11.2 q 32.33(20,608,246-107,287,476) \times 1$ & LOSS & $86,679,230$ \\
\hline 8 & arr 15q11.1q26.3(20,686,219-102,383,444)×2 3 & GAIN & $81,697,225$ \\
\hline 9 & arr 16q11.2q24.3(46,500,771-90,148,364)×1 2 & LOSS & $43,647,593$ \\
\hline 10 & arr 18p11.32q23(148,993-78,012,800)×2 3 & GAIN & $77,863,807$ \\
\hline
\end{tabular}

of other array and CGH studies [15]. However, there was a similar trend of genetic imbalances with a loss of 16q. These genetic imbalances may contribute to late tumorigenesis. Our hypothesis is that a DNA repair system failure induces FOXL2 402C > G mutation, followed by granulosa cell tumor development. The same mechanism randomly causes further mutations of tumor suppressor genes or oncogenes, resulting in late recurrence and unpredictable malignant behavior of granulosa cell tumor. However, we cannot dismiss the possibility that the amino acid changing mutation in FOXL2 402C > G is the driver mutation that leads to subsequent genomic alterations in granulosa cell tumor pathogenesis.

\section{Conclusions}

Adult-type granulosa cell tumors are associated with FOXL2 402C > G mutation. In addition to this unique FOXL2 mutation, we found DNA replication error and loss of heterozygosity in this case. DNA mismatch repair

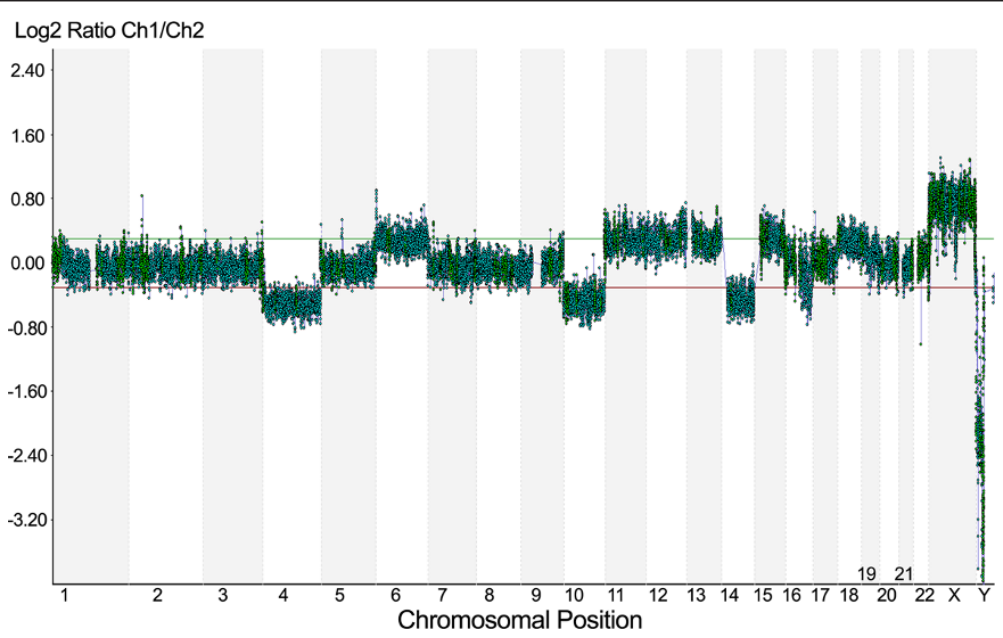

Figure 4 Array comparative genomic hybridization (aCGH) analysis: Whole genome view on comparative genomic hybridization array (CytoChip Oligo Array) shows pathological genetic imbalances in many chromosomes in the tumor. 
system failure appears likely in this patient. In such a case, early detection allows for treatment of benign tumor. Although this study could not elucidate the exact mechanism for the development of granulosa cell tumor, it does suggest the need to incorporate DNA mismatch repair system examination into the clinical management of patients with granulosa cell tumor.

\section{Consent}

Written informed consent was obtained from the patient for publication of this Case report and any accompanying images. A copy of the written consent is available for review by the Editor-in-Chief of this journal.

\section{Abbreviations}

aCGH: Array comparative genomic hybridization; FIGO: The International Federation of Gynecology and Obstetrics; FOXL2: Forkhead box L2; LOH: Loss of heterozygosity; MLH1: MutL homolog 1; PCR: Polymerase chain reaction; STR: Short tandem repeat.

\section{Competing interests}

The authors declare that they have no competing interests.

\section{Authors' contributions}

YCL designed the experiments, performed the experiments, interpreted the results, and drafted the manuscript. WWC designed the experiments, provided samples and clinical data, interpreted the results and made critical revisions to the manuscript. Both authors have read and approved the final manuscript.

\section{Author details}

'Department of Obstetrics and Gynecology, Jen-Ai Hospital, Taichung, Taiwan. ${ }^{2}$ School of Medical Laboratory and Biotechnology, Chung Shan Medical University, No.110, Sec. 1, Chien Kuo N. Road, Taichung 402, Taiwan.

Received: 1 April 2014 Accepted: 31 August 2014

Published online: 06 September 2014

\section{References}

1. Jamieson S, Fuller PJ: Molecular pathogenesis of granulosa cell tumors of the ovary. Endocr Rev 2012, 33:109-144.

2. Scully RE: Classification of human ovarian tumors. Environ Health Perspect 1987, 73:15-25.

3. Crum CP, Nucci MR, Lee KR: Sex cord-stromal and miscellaneous tumors of the ovary. In Diagnostic Gynecology and Obstetrics Pathology. Edited by Crum CP, Nucci MR, Lee KR. Philadelphia: Elsevier; 2011:938-971.

4. Shah SP, Kobel M, Senz J, Morin RD, Clarke BA, Wiegand KC, Leung G, Zayed A, Mehl E, Kalloger SE, Sun M, Giuliany R, Yorida E, Jones S, Varhol R, Swenerton KD, Miller D, Clement PB, Crane C, Madore J, Provencher D, Leung P, DeFazio A, Khattra J, Turashvili G, Zhao Y, Zeng T, Glover JN, Vanderhyden $B$, Zhao $C$, et al: Mutation of FOXL2 in granulosa-cell tumors of the ovary. N Engl J Med 2009, 360:2719-2729.

5. Schumer ST, Cannistra SA: Granulosa cell tumor of the ovary. J Clin Oncol 2003, 21:1180-1189.

6. Amsterdam A, Selvaraj N: Control of differentiation, transformation, and apoptosis in granulosa cells by oncogenes, oncoviruses, and tumor suppressor genes. Endocr Rev 1997, 18:435-461.

7. Ala-Fossi SL, Maenpaa J, Aine R, Koivisto P, Koivisto AM, Punnonen R: Prognostic significance of p53 expression in ovarian granulosa cell tumors. Gynecol Oncol 1997, 66:475-479.

8. Roush GR, El-Naggar AK, Abdul-Karim FW: Granulosa cell tumor of ovary: a clinicopathologic and flow cytometric DNA analysis. Gynecol Oncol 1995, 56:430-434

9. Schrader KA, Gorbatcheva B, Senz J, Heravi-Moussavi A, Melnyk N, Salamanca C, Maines-Bandiera S, Cooke SL, Leung P, Brenton JD, Gilks CB, Monahan J, Huntsman DG: The specificity of the FOXL2 c.402C > G somatic mutation: a survey of solid tumors. PLoS One 2009, 4:e7988.
10. Kittles RA, Young D, Weinrich S, Hudson J, Argyropoulos G, Ukoli F, Adams-Campbell L, Dunston GM: Extent of linkage disequilibrium between the androgen receptor gene CAG and GGC repeats in human populations: implications for prostate cancer risk. Hum Genet 2001, 109:253-261.

11. Wang WC, Lee MS, Ko JL, Lai YC: Origin of uterine teratoma differs from that of ovarian teratoma: a case of uterine mature cystic teratoma. Int $J$ Gynecol Pathol 2011, 30:544-548.

12. Sun HD, Lin $H$, Jao MS, Wang KL, Liou WS, Hung YC, Chiang YC, Lu CH, Lai HC, Yu MH: A long-term follow-up study of 176 cases with adult-type ovarian granulosa cell tumors. Gynecol Oncol 2012, 124:244-249.

13. Rosario R, Araki H, Print CG, Shelling AN: The transcriptional targets of mutant FOXL2 in granulosa cell tumours. PLOS One 2012, 7:e46270

14. Suzuki M, Ohwada M, Saga Y, Ochiai K, Sato I: DNA replication error is frequent in ovarian granulosa cell tumors. Cancer Genet Cytogenet 2000, 122:55-58.

15. Geiersbach KB, Jarboe EA, Jahromi MS, Baker CL, Paxton CN, Tripp SR, Schiffman JD: FOXL2 mutation and large-scale genomic imbalances in adult granulosa cell tumors of the ovary. Cancer Genet 2011, 204:596-602.

doi:10.1186/s13048-014-0088-0

Cite this article as: Wang and Lai: Molecular pathogenesis in granulosa cell tumor is not only due to somatic FOXL2 mutation. Journal of Ovarian Research 2014 7:88.

\section{Submit your next manuscript to BioMed Central and take full advantage of:}

- Convenient online submission

- Thorough peer review

- No space constraints or color figure charges

- Immediate publication on acceptance

- Inclusion in PubMed, CAS, Scopus and Google Scholar

- Research which is freely available for redistribution 